\title{
PHYSIOLOGY AND ENDOCRINOLOGY OF THE FOETUS IN LATE GESTATION
}

\author{
A.A. MACDONALD, B. COLENBRANDER and C.J.A.H.V. VAN \\ VORSTENBOSCH
}

Institute of Veterinary Anatomy, State University of Utrecht, The

Netherlands

Birth, the transfer from liquid space to gaseous atmosphere confronts the mammalian organism with substantial and novel challenges. If the genotype of the newborn, indeed the species, is to reproduce further, it must survive. In the case of the pig, survival is so commonplace that the miracle of coordination required to achieve it is often overlooked; after all, about eight out of every ten newborn piglets succeed in making the transition (Randall, 1978). How do they manage this remarkable feat and what do they require at birth to survive?

Clearly while in utero the placenta, perfused with foetal blood, abstracts from the maternal circulation the gases, metabolites and minerals necessary for growth. This supply is severed at birth and to survive the piglet must obtain oxygen and remove carbon dioxide. Failure to do so leads to death within minutes (Miller and Miller, 1965).

The lung, therefore, must be fully competent at birth to take over the role of gas exchange with the circulation from the placenta. How it develops that ability, and an examination of the factors which may contribute to its development, form part of this review.

Nutrient supply, its distribution, and metabolite clearance during gestation are designed for the buffered, aquatic environment in utero. Birth disrupts this, thrusting upon the neonate a gaseous environment, atmospheric pressures, an expanded pulmonary circulation and the destruction of the placental supply.

What developments during gestation contribute to piglet competence to cope with such changes? For example, how is the homoeostasis of the circulation maintained; are the nervous faculties developed; how is it that the piglet can stand, balance and move; what must be present to enable the piglet to locate the udder and its new supply of nutrients? This chapter will examine what is known of such developments, indicate a number of the many gaps in that knowledge, and finally ask whether we know when, or how this complex piece of expressed genotype acquires the wherewithal to protect itself against the cold, disease and competition awaiting it after birth. 


\section{The development of the lung}

The lung acquires the function of gas exchange at birth, respiration up until that time having been performed by the placenta. At mid-gestation the lung is a somewhat glandular mass of mesenchymal tissue (Figure 18.1 (a)) and quite unsuitable for respiratory gas exchange (Flint, 1906-07; Clements, 1938). Nevertheless by 80 days of gestation well-defined bronchi

(a)

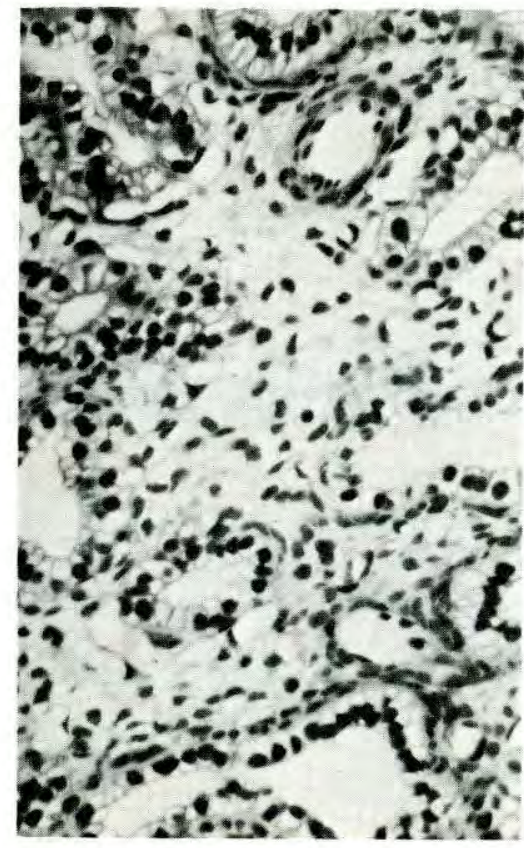

(b)

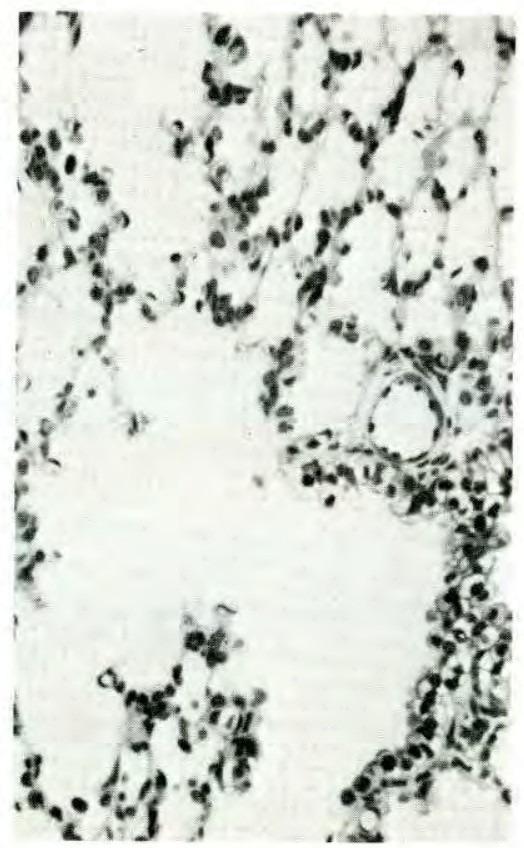

Figure 18.1 (a) Section of foetal pig lung at 70 days of gestation to demonstrate the glandlike appearance of the tissue between the mesenchyme. (b) Section of foetal pig lung at 112 days of gestation to demonstrate a terminal bronchiole leading into an alveolar duct and a cluster of alveoli. (Magn. $\times 290$ )

are present and some ten days later the epithelial cells of the bronchi are differentiated into ciliated and goblet cells (Baskerville, 1976). Likewise, whereas at 80 days the alveoli have a cuboidal or columnar epithelium, this changes to a mainly squamous type by about 90 days of gestation; differentiating type II alveolar cells may be identified by the osmophilic lamellar bodies seen in their cytoplasm.

Clusters of goblet cells with the appearance of primitive glands can be found in the bronchi at this stage of development and during the remaining three weeks of gestation they increase in number and size. Also in the bronchi, the ciliated cells increase in number such that by term they represent almost two thirds of the bronchial epithelium (Baskerville, 1976).

The shape of the alveoli changes during the last three weeks of gestation. The more or less rounded form gives way to the irregular open lattice 
pattern (Figure 18.1 $(b)$ ) seen in the perinatal animal (Clements, 1938; Ham and Baldwin, 1941). The surface of the alveoli becomes covered for the most part by squamous type I alveolar cells and the type II alveolar cells increase their content of lamellar bodies (Rufer and Spitzer, 1974; Baskerville, 1976).

Studies on other species have demonstrated that it is the phospholipid material of which the lamellar bodies are composed that is responsible for forming a surfactant film over, and thereby holding the postnatal stability of, the alveoli and alveolar ducts. Between days 95 and 110 of gestation there is a sharp increase in both phospholipid content and in vitro lecithin production by the lung (Rufer and Spitzer, 1974). The five-fold increase in foetal pig lung compliance is consistent with these findings. Somewhat surprisingly, however, it is not the intrinsic elasticity of the phopholipid surfactant film, but rather the change in the film's surface tension that modifies lung compliance (Meban, 1980).

\section{LUNG GLYCOGEN}

The development of the foetal lung is also reflected in the decrease in its glycogen content as shown in Figure 18.2. Glycogen, which in the lung

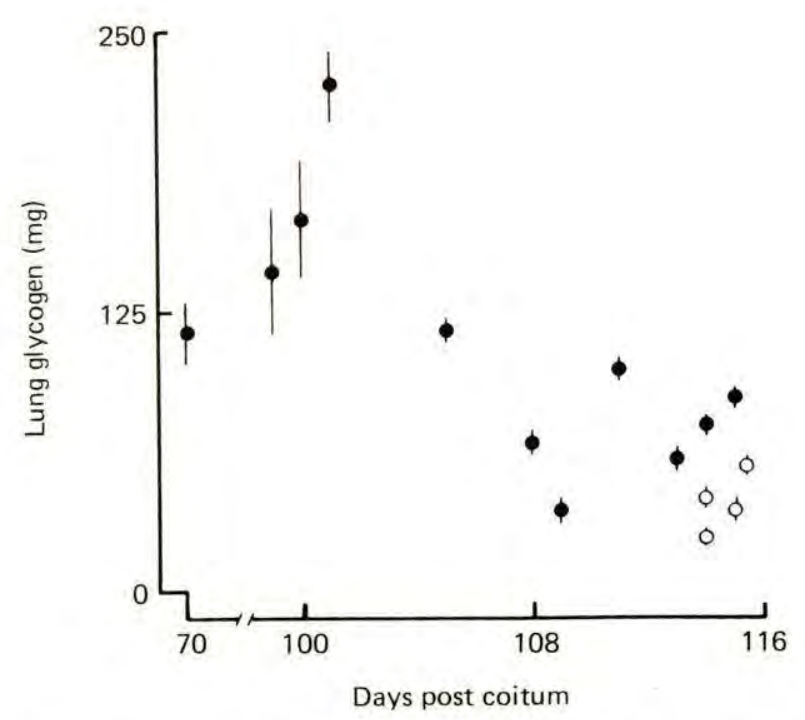

Figure 18.2 The decrease in lung glycogen $(\tilde{x} \pm$ S.E.M. $)$ during the last two weeks of gestation. = prenatal; $\bigcirc=$ neonatal. From Macdonald (1974)

provides a local energy substrate for differentiation, is distributed throughout the epithelia of the alveoli, respiratory bronchioles and bronchi at about 100 days gestation. By the end of gestation, little of the polysaccharide remains in the alveoli, although its presence may be detected in the bronchial epithelium (Macdonald, 1974). 


\section{LUNG FLUID}

The airways at term are filled with fluid (Figure 18.1(b)) produced by the lung tissue during the last part of gestation (Berton, 1970; Baskerville, 1976). This is removed from the airways during birth and very soon thereafter. The amount cleared from the foetal pig lung can be estimated from the sharp reduction in lung weight following birth shown in Figure 18.3. Studies on other species indicate that this fluid is lost as a result of

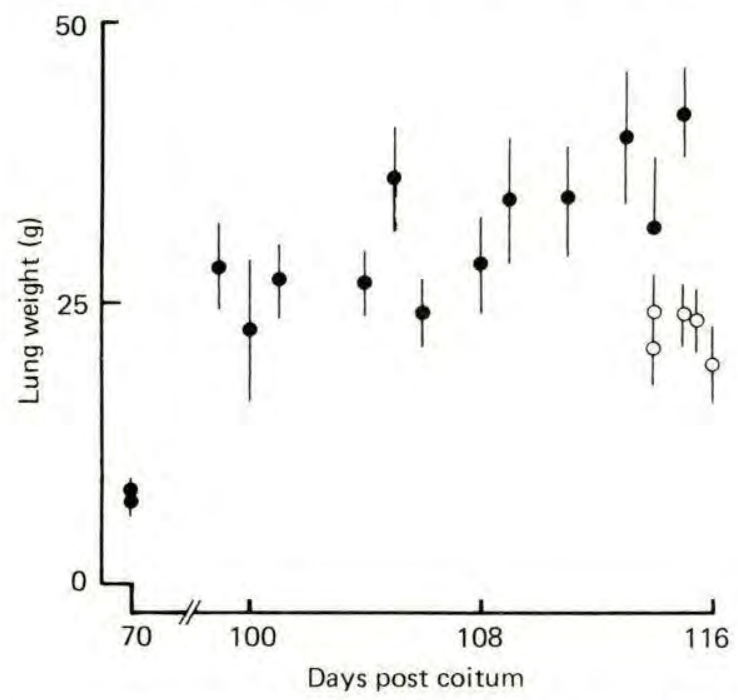

Figure 18.3 The fresh weight of lung tissue (and fluid contents) sectioned at the tracheal bifurcation: - prenatal; $\mathrm{O}=$ neonatal. From Macdonald (1974)

increased lymph drainage (Bland, McMillan and Bressack, 1977). A number of hormonal factors may control foetal lung development, so it is necessary to examine the foetal growth of those endocrine glands which are suspected of influencing lung maturation.

\section{The adrenal}

The role which glucocorticoids may play in foetal lung maturation has recently been reviewed (Olson, 1979), and it is clear that the interrelationship between the development of the lung and the hormones of the adrenal may be more complex than had earlier been appreciated. The adrenal gland has a definitive cortex by mid-gestation (Figure 18.4(a)) and, as shown by Flint (1900) and Whitehead (1903), increases in size and structural organization towards term (Figure 18.4(b)). Some recent studies have resulted in an array of cortical cells being termed the 'foetal cortex'; these cells, found intermingled with medullary tissue at mid-gestation, were reported to be replaced with true cortical tissue by about 80 days of gestation (Katznelson, 1965, 1966; Sedova, 1974). Preliminary results of a 
(a)

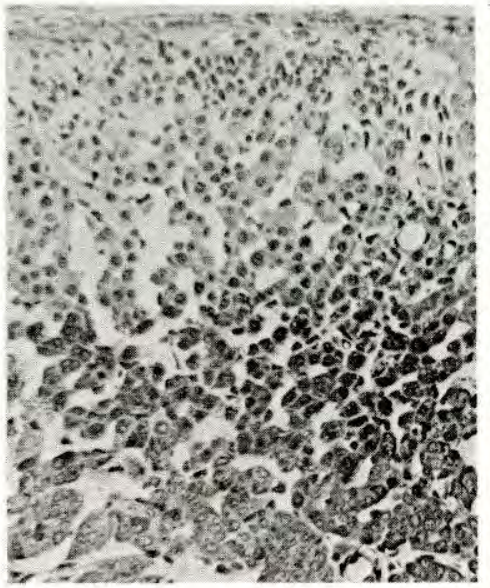

(b)

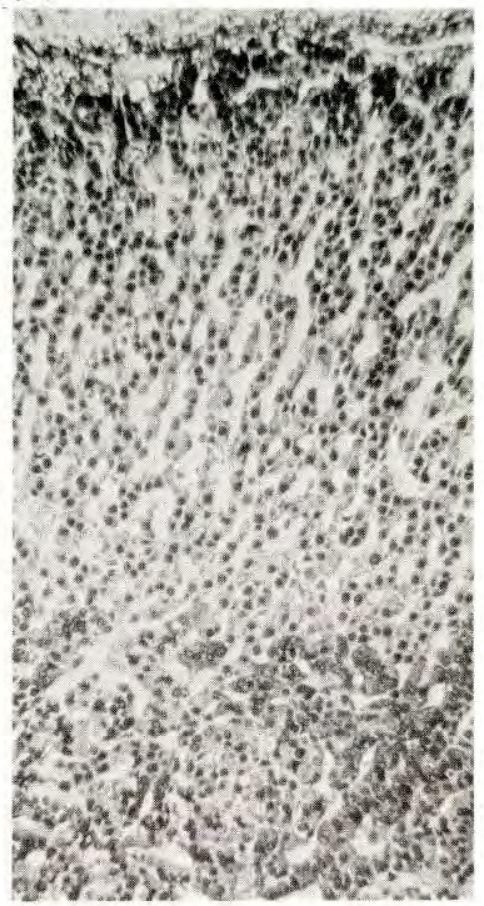

Figure 18.4 (a) Cross section of foetal pig adrenal at 70 days of gestation to illustrate the clustered (pale coloured) cortical tissue above the cells of the medulla. (b) Cross section of foetal pig adrenal at 112 days of gestation to illustrate development of cortical tissue into cords. (Magn. $\times 160$ )

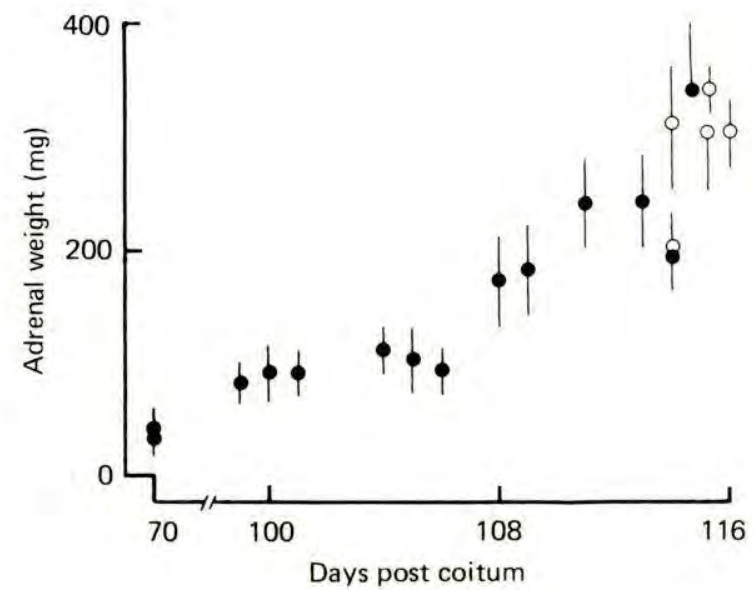

Figure 18.5 The increase in total adrenal tissue weight of pig foetuses during the last two weeks of gestation: $=$ prenatal; $\bigcirc=$ neonatal. From Macdonald (1974) 
re-examination of adrenal development could find no histological or histochemical grounds for a distinction between 'foetal' and reticularis cells of the true cortex (Colenbrander, Macdonald and Wensing, unpublished observations).

During the last two weeks before term adrenal weight increases rapidly (Figure 18.5) and at a rate faster than foetal body weight (Dvorak, 1972; Lohse and First, 1979). Corticosteroids are produced by the adrenal even more rapidly (Dvorak, 1972; Lohse and First, 1979) and this is reflected in circulating concentrations of $17 \beta$-hydroxy corticosteroids (Dvorak, 1972) and cortisol (Fèvre, 1975), the latter being the hormone with greatest activity (Figure 18.6). However, the rise in circulating corticosteroid levels

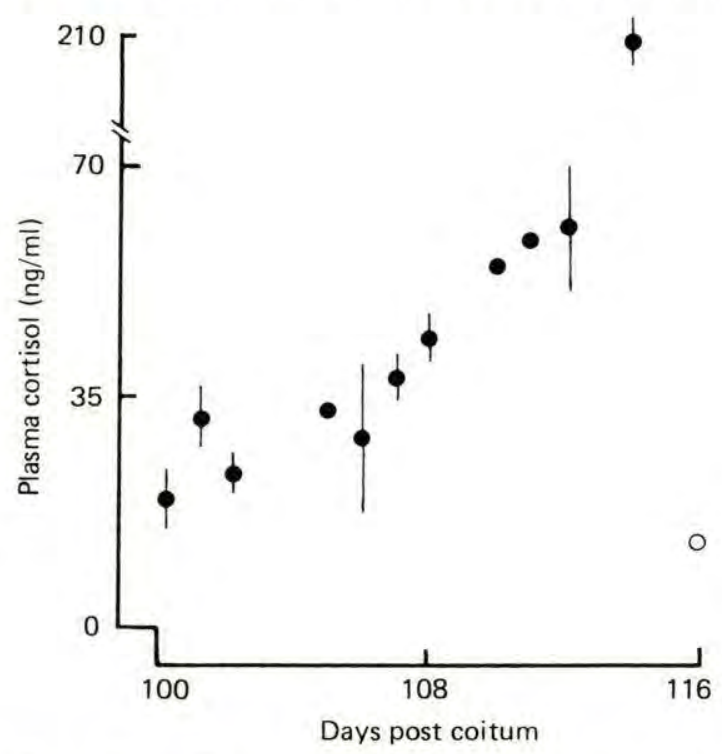

Figure 18.6 The rise in cortisol concentrations measured in foetal pig plasma during the last two weeks of gestation: - prenatal; $\bigcirc=$ neonatal. From Fèvre (1975)

is not well correlated to the timing of foetal lung maturation. It may be, therefore, that as in the foetal rabbit (Nicholas et al., 1978) the lung of the pig foetus contains enzymes which can convert inactive corticosteroids into cortisol at a stage of gestation earlier than that at which cortisol is seen to increase in the general circulation. Alternatively the lung may develop as a consequence of an increased hormonal receptor population, or as a result of other hormonal action.

\section{The thyroid}

Hormones from the foetal thyroid may be associated with the development of the foetal pig lung. Anatomical studies demonstrate that thyroid follicular development has become established by about 75 days of gestation (Moody, 1906; Studzinski, Bobowiec and Rybka, 1976). However, biochemical studies reviewed recently indicate that there is little change 
in the glandular production or circulating concentrations of thyroid hormones between 75 days of gestation and term (Macdonald, 1979; Colenbrander et al., 1980).

\section{The pancreas}

Pancreatic hormones, and in particular insulin, may play a role in type II cell maturation. Microscopic studies have demonstrated that the cell of the islets of Langerhans increase in number and size after about 95 days gestation (Aron, 1922; Comline et al., 1981). The pronounced proliferation of insulin-producing cells is also reflected in the sharp increase by day 100 in the circulating concentrations of insulin (Atinmo et al., 1976; Fowden, Comline and Silver, 1981; Comline et al., 1981).

Thus the alveolar type II cell development takes place against an apparently stable background of adrenocorticosteroid and thyroid hormones and is possibly in parallel with changes in the pancreatic production and secretion of insulin. Do these hormones influence lung development? What role does the nervous system or prolactin play? It is clear that further study is required before the functional development of the pig's type II alveolar cells is fully understood.

\section{The heart and circulation}

The demands placed on the foetal heart are, as in the adult, those of distribution of nutrients and removal of metabolites. It is not surprising, therefore, that there is a close linear relationship between the growth of the heart and either the increase in foetal body weight or the increase in weight of the foetal body plus placental membranes, the latter being a more appropriate description of the total mass of tissue perfused by the foetal blood stream (Macdonald, 1971; Macdonald, unpublished observations).

\section{THE CIRCULATION}

The pattern of the circulation during foetal life is specifically adapted to the intrauterine environment (Figure 18.7(a)). It has been known for some time that some of the blood returning in the venae cavae passes through the foramen ovale (Pohlman, 1909; Kellogg, 1928). During gestation the lungs receive only a small proportion of combined ventricular output, much of the cranial vena cava return flowing via the ductus arteriosus to the aorta (Macdonald, Rudolph and Heymann, unpublished observations). About $30 \%$ of combined ventricular output flows to the placenta (Macdonald, Rudolph and Heymann, 1980). The venous return from the placenta passes through the ductus venosus in the liver (Figure 18.7(a)) and flows with the venous drainage from the lower body tissues back to the heart (Pohlman, 1909; Kaman, 1968a; Barnes et al., 1979). 

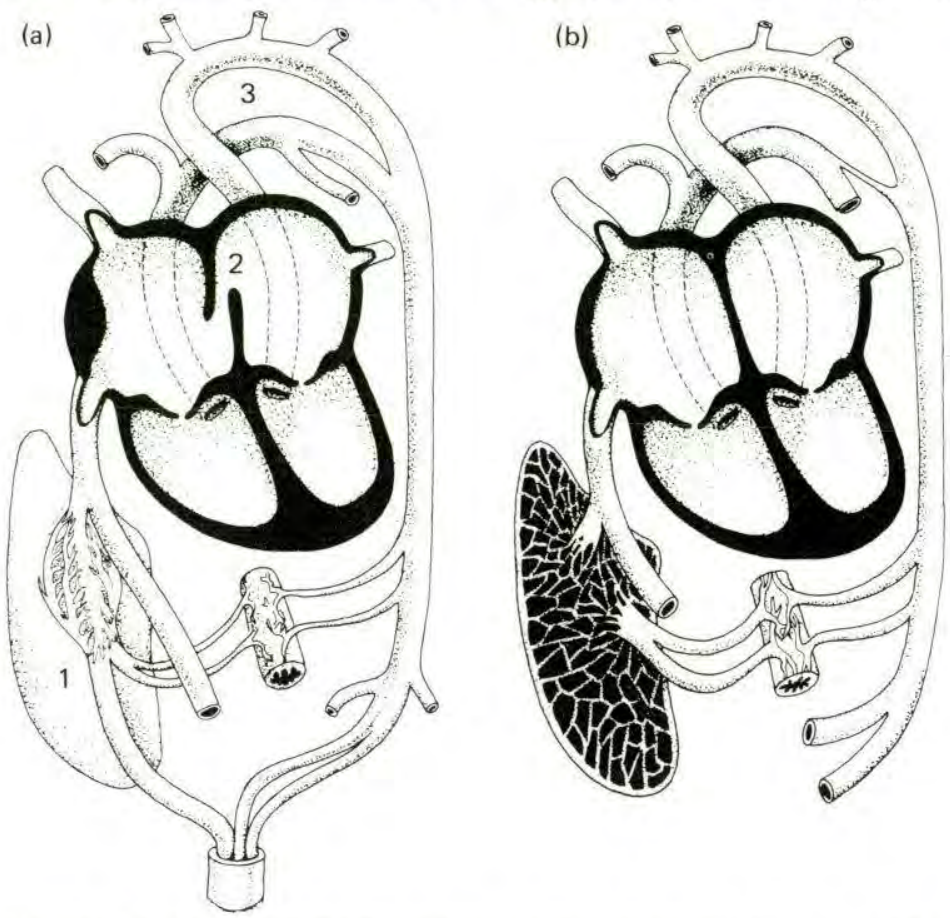

Figure 18.7 (a) Schematic diagram to illustrate the foetal circulation. The umbilical venous return from the placenta passes through the ductus venosus (1) in the liver and joins the caudal vena cava flow to enter the right atrium. The left and right atria connect through the foramen ovale (2). Blood flows from the right ventricle mainly via the ductus arteriosus (3) into the aorta. (b) Schematic diagram to indicate the developed postnatal circulation. Venous return from the intestine enters the liver. There is no flow from right to left atrium. The ductus arteriosus is closed. Blood flows from the right ventricle to the lungs, from the left ventricle to the aorta.

Following birth this circulatory path changes (Figure 18.7(b)). The placenta is no longer part of the piglet's general circulation. The lung takes over the respiratory function of the placenta and blood flow is directed along the pulmonary arteries as a result of the gradual closure of the ductus arteriosus (Evans et al., 1963; Rowe et al., 1964). Recent studies have shown that the patency of the ductus arteriosus can be maintained by administration of prostaglandins of the $\mathrm{A}$ and $\mathrm{E}$ series, or their analogues (Starling et al., 1976, 1978). The disruption at birth of the endogenous production of these substances is probably responsible for the closure of this foetal vessel. As blood pressure in the systemic circulation rises above that in the pulmonary circulation the valve-like foramen ovale is more often held shut than open and the opening is gradually sealed (van Nie et al., 1970; Versprille et al., 1970). The ductus venosus no longer receives blood from the umbilical vein, which closes (Kaman, 1968b).

\section{CONTROL OVER THE HEART AND CIRCULATION}

At about four weeks before birth the mean pressure within the arteries of the foetus is $38 \mathrm{~mm} \mathrm{Hg}$ (Macdonald et al., 1981b) and, as shown in Figure 


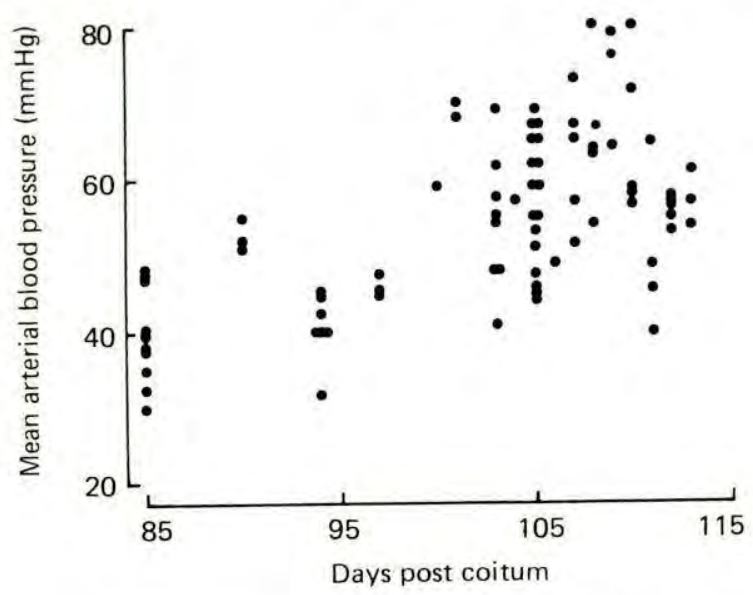

Figure 18.8 Mean arterial blood pressure measured in chronically catheterized pig foetuses during the last month of gestation.

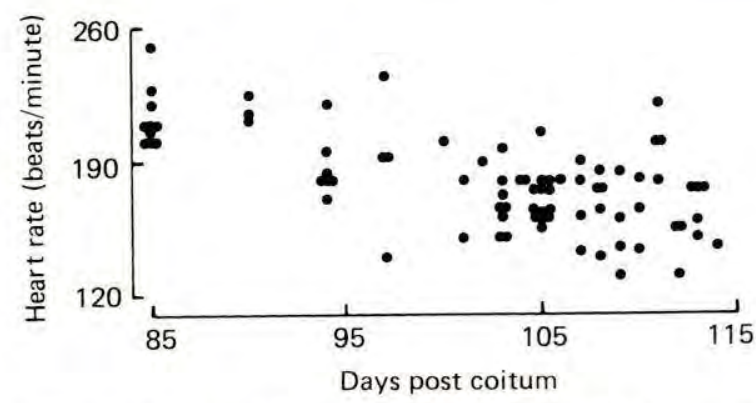

Figure 18.9 Heart rate measurements made on ch:onically catheterized pig foetuses during the last month of gestation.

18.8, there is a gradual increase until term, although a pronounced variability is seen between foetuses of similar age. Over the same period of time (Figure 18.9) foetal heart rate slows down (Fraser, Nagaratnam and Callicott, 1971; Too et al., 1974; Macdonald et al., 1981b).

In the adult, control over the heart and circulation is exerted by a complex array of hormonal, nervous and physical factors (Guyton, Coleman and Granger, 1972). Substantially less is known, however, about which of these mechanisms is available to the foetus for controlling its circulation, and to what extent they are used during the transition to postnatal life.

\section{Neural control}

Anatomical studies of the heart clearly demonstrate that neural elements are laid down early in gestation (Wensing, 1964) and that both catecholamine- and acetylcholinesterase-containing fibres are present and increase in number as gestation proceeds (Macdonald et al., 1981a). It has also been 
shown recently that the foetal heart is responsive during the last month of gestation to both catecholamines (or their agonists) and acetylcholine (Comline, Fowden and Silver, 1979; Macdonald et al., 1981b; Macdonald and Colenbrander, 1981). Thus the heart of the pig foetus possesses end organ receptors sensitive to neurotransmitters. In order to test whether the nerves observed anatomically are physiologically functional, the endogenous catecholamine action was blocked with propranolol and the vagal action was blocked with atropine (Macdonald et al., 1981b). The heart rate slowed or accelerated respectively in response to the two drugs, indicating that the heart was under functional nervous control. The increase in responsiveness between 85 days gestation and term was interpreted as a sign of development within the system during the last month of gestation.

The neural control of the vasculature was similarly tested. Injection of methoxamine caused the blood pressure to increase as a result of peripheral vasoconstriction (Macdonald et al., 1981b; Macdonald and Colenbrander, 1981). Blockade of endogenous $\alpha$-sympathetic action with phentolamine resulted in a fall in blood pressure.

The enzymes monoamine oxidase and catechol-O-methyl transferase are responsible for deactivation of catecholamines and they are present in the heart during the last 10 days of gestation with high and increasing activity (Stanton et al., 1975).

\section{Adrenal hormones}

Catecholamines are also produced by cells of the adrenal medulla (see Figure 18.4(a) and $(b)$ ) which histological studies have demonstrated increases in amount during the second half of gestation (Flint, 1900; Wiesel, 1901; Fenger, 1912; Weymann, 1922-23). The concentration of norepinephrine in the gland at birth is $1.65 \mathrm{mg} / \mathrm{g}$ and norepinephrine represents $72 \%$ of the gland's total catecholamine content (Stanton and Woo, 1978). Although no measurements appear to have been made of foetal gland catecholamine content, preliminary results of histological studies suggest that the number of cells containing epinephrine increases during gestation (Verhoffstad, personal communication). This is a trend consistent with that seen after birth in biochemically measured epinephrine content (Stanton and Woo, 1978).

Among the factors known to act on the development of the sympathetic system are the adrenal corticosteroids. Evidence to support this view is the poor development of epinephrine-containing cells in the medulla of pig foetuses whose cortex has been stunted by removal of ACTH support through chronic foetal decapitation (Verhofstad et al., 1981).

\section{Renin-Angiotensin}

Another substance which may have an influence on foetal cardiovascular function is angiotensin II. This hormone is produced from a precursor plasma globulin, angiotensinogen, following the actions first of the proteolytic enzyme renin (to produce physiologically inactive angiotensin I) 
(a)

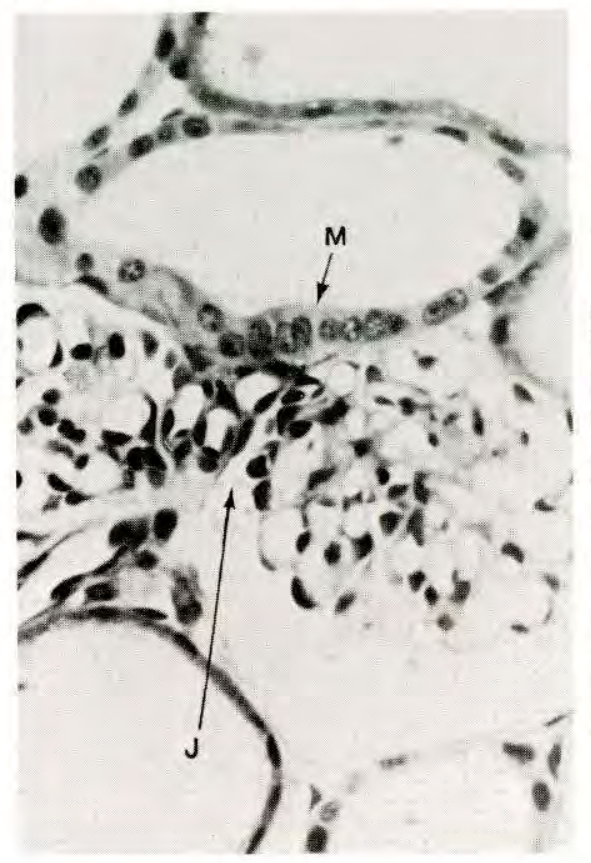

(b)

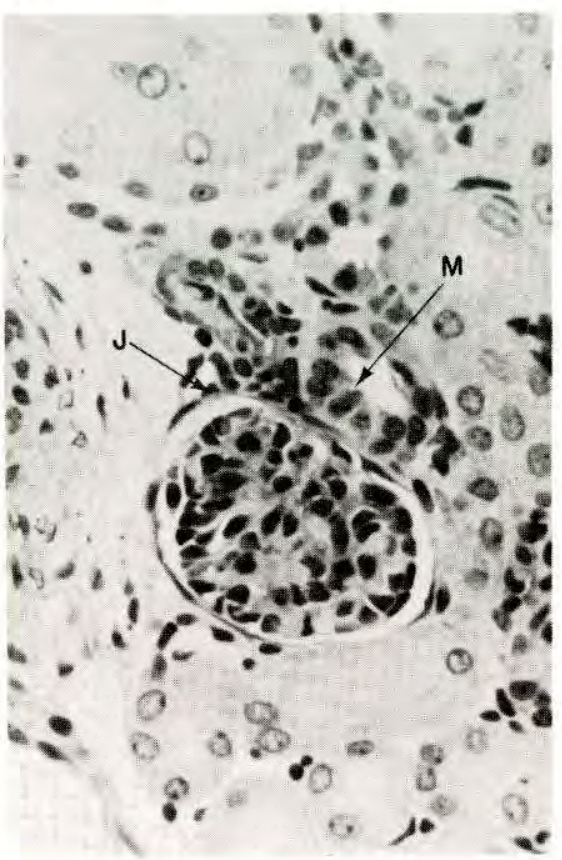

Figure 18.10 Sections of foetal pig kidney at (a) 70 days of gestation and (b) 112 days of gestation illustrating juxtaglomerular cells $(\mathrm{J})$ lying between the glomerulus and the macula densa $(M)$ of the collecting tubule. (Magn. $\times 400$ )

and then of a converting enzyme which is a protein circulating in the blood plasma. Renin is produced in response to a variety of stimuli by the juxtaglomerular cells of the kidney (Figure 18.10). The foetal development of these cells has not been studied in the pig, but an account of their appearance in the kidney of the newborn piglet has been given by Kazimierczak (1970). In vitro culture of kidney cortex from pig foetuses at approximately 65 days gestation resulted in renin production (Szalay and Gyevai, 1967). Earlier studies in which extracts were made of kidney from foetuses aged between 35 days and term demonstrated a gestational trend of increased pressor activity/gram of kidney extract particularly during the last month of gestation (Kaplan and Friedman, 1943). Therefore, although angiotensin II has not yet been measured in the circulation of the pig foetus, these studies when taken together with the observation that plasma angiotensin II concentrations are elevated in the newborn piglet (Osborn, 1979), would imply foetal competence to produce the hormone.

The role which the renin-angiotensin system may play in aldosterone secretion by the adrenal is also presently unknown in the pig foetus. Furthermore the part which aldosterone plays in conjunction with the other physiological mechanisms in the maintenance of foetal blood pressure and volume remains to be investigated. 


\section{Fluid balance}

The control of fluid balance is more difficult to study in the foetus than the neonate or adult animal because of the larger number of tissues and compartments through which minerals and solutes may be exchanged. In addition to the placenta, foetal membranes and umbilical cord, fluid can transfer through the foetal skin (France, 1976). It is also produced by the foetal lung as mentioned earlier (p.380), either to be swallowed with amniotic fluid, or expelled into the amniotic cavity by intrauterine breathing, sighing and gasping movements (Randall, 1978; 1979). Urine is produced by the foetal kidneys, but is excreted not only into the amniotic cavity via the urethra, but also to the allantoic cavity via the urachus; it is this aspect of fluid balance which has been the most accessible to study.

During the second half of gestation the microscopic anatomy of the kidney changes. At about mid-gestation the glomeruli are large, have an 'open' appearance and are relatively few in number, lying surrounded by proximal tubules with wide internal diameters (Figure 18.11(a)). By the end of gestation the glomeruli have increased in number and are more densely packed together (Figure 18.11(b)); individually the glomeruli appear to have a more intricate structure and all stages of their development can be seen in the zone of growth of the outer cortex. More tubules

(a)

(b)

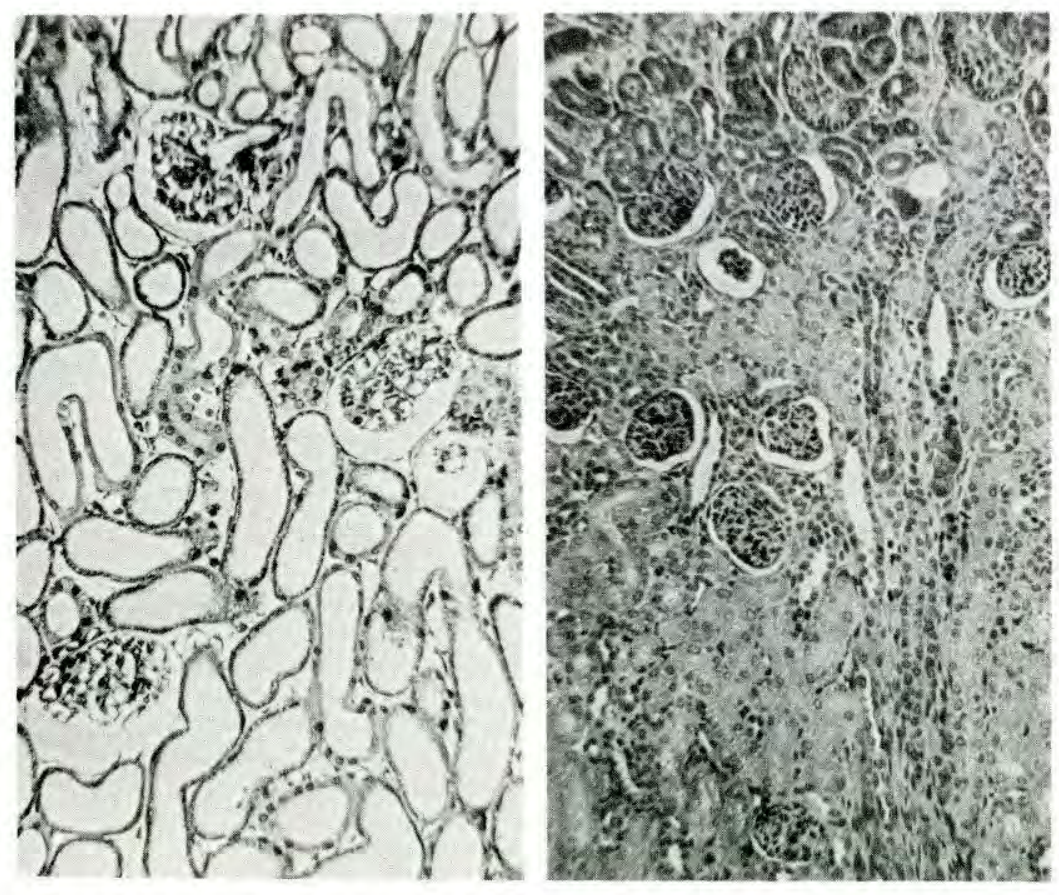

Figure 18.11 (a) Section of foetal pig kidney at 70 days of gestation demonstrating the large glomeruli and large fluid-filled proximal tubules. (b) Section of foetal pig kidney at 112 days of gestation illustrating the cortical zone of differentiating glomeruli (top) and the compact glomeruli surrounded by densely packed tubules. (Magn. $\times 150$ ) 
are present and their diameters are smaller (Hill, 1905; Kunska, 1971a, b; Bergelin and Karlsson, 1975).

By about 70 days of gestation urine flow is estimated to be $33 \mu \mathrm{l} / \mathrm{minute} / \mathrm{g}$ kidney weight (Perry and Stanier, 1962) and the decrease to $5.4 \mu \mathrm{l} / \mathrm{minute} /$ g kidney weight at birth (Joppich et al., 1979) reflects the development of competence by the perinatal kidney to produce a more concentrated urine (McCance and Stanier, 1960; Alt et al., 1981). The studies by Alt et al. (1981) have demonstrated that although the kidneys of foetuses one week before birth are functionally quite mature, they are nevertheless significantly less mature than those of piglets one week after birth. The mechanism whereby this is brought about remains a matter of speculation.

\section{The nervous system}

It is necessary for the brain and peripheral nervous system to possess a large degree of functional competence at birth. The morphological development of the central nervous system in the pig has been studied qualitatively by Bradley (1903), Larsell (1954) and Welento $(1960 ; 1961)$. Quantitative studies have demonstrated that the brain rapidly increases in weight through the last month of gestation and the first month after birth. Although the rate of total brain growth does not seem to change during this period, the different constituent parts of the brain do show differing rates of growth (Pomeroy, 1960; Dickerson and Dobbing, 1966; Done and Herbert, 1968; Brooks and Davis, 1969). The complexity of brain development is, however, poorly represented by gross morphological or morphometric observations alone.

Increases in total cell number are reflected in the concentration of DNA-P which in the cerebellum and brainstem is seen to rise to a peak at 95 days, the increase occurring somewhat earlier in other parts of the brain (Dickerson and Dobbing, 1966). The number of neurons, as indicated by the concentration of gangliosides, sharply increases during the last three weeks of gestation (Dickerson, Merat and Widdowson, 1971). The number of synaptic complexes isolated biochemically from the cerebellum increases with foetal maturation in line with the change seen in the morphology of the cells. At 70 days of gestation the predominant synaptic complex is associated with climbing fibre terminals whereas parallel fibre terminals predominate after birth (Kornguth et al., 1972).

In the near term pig foetus electrical activity has been recorded from cells of the post-central gyrus of the cerebral cortex and the patterns of activity were very similar to those observed in prepubertal animals (Konda et al., 1979). Stimulation of particular sites in the brain stem of the newborn pig produced appropriate changes in heart rate and blood pressure, indicating that the cardiovascular regulatory centres of the piglet are functional at birth (Gootman et al., 1972; Marshall and Breazile, 1974a, b; Gootman, Buckley and Gootman, 1978; 1979).

The concentration of cholesterol in various parts of the brain and spinal cord (Dickerson and Dobbing, 1966) is closely correlated to myelination of the foetal nervous system during the last month of gestation (Ziolo, 1965; Majstruk-Majewska, 1966). The amount of myelin in the spinal cord, for 
example, increased from $33.3 \pm 1.9 \mathrm{mg} / \mathrm{g}$ fresh tissue at 100 days of gestation to $50.0 \pm 2.29 \mathrm{mg} / \mathrm{g}$ at birth (Patterson et al., 1976).

\section{THE SENSES}

It is pertinent to ask in what way development proceeds with regard to the various organs which will sense the new environment. To be successful in obtaining food the newly born piglet must manage to get from the rear of the sow to the udder. To do this effectively it should be able to maintain some degree of balance. Moreover, it is conceivable that one or several of the senses - sight, touch, hearing, taste, smell-are involved in guiding the newborn to the new site of nutrient supply.

Very little is known about the development in utero of these senses in any species of animal (Gottlieb, 1971; Bradley and Mistretta, 1975), although a general ontogenetic sequence would appear to be touch, balance, hearing and sight. Spinal reflexes and responsiveness to touch are present by at least 40 days of gestation (Carey, 1922-23; Macdonald, unpublished observations). Anaesthetized chronically decapitated pig foetuses show greater sensitivity to touch than control foetuses (Stryker and Dziuk, 1975; Kraeling et al., 1978). In view of the importance of the pig's snout as a tactile organ after birth (Adrian, 1943a, b; Woolsey and Fairman, 1946), information concerning its prenatal development would be of interest. The same may be said for the senses of balance and taste, although fragmentary information concerning their embryological development is present in the earlier literature (see Patten, 1931).

Studies of the developmental anatomy of the ear suggest that it may be responsive to sound during the second half of gestation (Prentiss, 1913; Hardesty, 1915). However, no studies on the piglet have been found in which the sensitivity of the ear to sound has been explored during gestation.

The eyes are open at birth, and it is clear from studies of their anatomical development that they already possess a high degree of structural organization by mid-gestation (Rabl, 1900; Kölliker, 1904). The extent to which the various structures are functional before birth remains unknown. However, recent studies indicate that all the adult components of visually evoked electroencephalograph responses are present at birth, though demonstrating signs of immaturity (Mattsson et al., 1978).

\section{AUTONOMIC NERVOUS SYSTEM}

Rather more information is available concerning the development of the autonomic nervous system, and in particular the development of foetal competence to recognize and respond to changes in blood pressure and oxygen supply. When blood pressure is reduced by removing $15-30 \%$ of foetal blood volume, a reflex increase in heart rate and increased circulating concentrations of lysine vasopressin are observed (Forsling, Macdonald and Ellendorff, 1979; Macdonald et al., 1979; Biermann et al., 1979). Similarly, when the foetal supply of oxygen is reduced by lowered maternal 
oxygen intake (Harris and Cummings, 1973), cord clamping (Randall, 1978, 1979; Forsling, Macdonald and Ellendorff, 1979) or complete removal from the uterus of the foetus within intact placental membranes (Vesalius, 1543; see Macdonald, 1981), then the heart rate of the foetus increases; gasping movements, recognizably different from normal intrauterine breathing movements (Randall, 1979) are also seen, and there is an increase in circulating vasopressin concentrations. The foetus becomes more responsive to these stimuli during the last month of gestation (Forsling, Macdonald and Ellendorff, 1979).

\section{PITUITARY AND HYPOTHALAMUS}

The foetal pituitary shows signs of considerable development during the second half of gestation and particularly during the last three weeks before term (Nelson, 1933; Liwska, 1975; 1978). Concentrations of the gonadotrophic hormones, LH and FSH, measured in the pituitary and general circulation rise to high levels before term (Melampy et al., 1966; Elsaesser et al., 1976; Colenbrander et al., 1977, 1980). The amount of prolactin in the pituitary and blood tissues increases similarly (Colenbrander et al., 1982).

In the foetal hypothalamus the development of neurophysin II containing elements is such that an adult-like pattern of distribution is achieved by the time of birth (Livett, Uttenthal and Hope, 1971; Ellis and Watkins, 1975). As gestation proceeds to term the amount of lysine vasopressin present in the pituitary increases (Perks and Vizsolyi, 1973) and is more readily released into the circulation following hypoxic or haemorrhagic stimuli (Forsling, Macdonald and Ellendorff, 1979; Biermann et al., 1979).

The importance of the pituitary-adrenal axis in parturition is implied by a number of observations. The concentration of circulating ACTH is high at the end of gestation (Brenner, Gurtler and Reinhardt, 1978), the adrenal responsiveness to ACTH increases towards term (Dvorak, 1972) and there is a sharp increase in circulating concentrations of corticosteroids prior to term (Fèvre, 1975; Silver et al., 1979). In addition, removal of the foetal pituitary, either by electrocoagulation (Bosc et al., 1979) or foetal decapitation (Stryker and Dziuk, 1975; Colenbrander et al., 1979) results in retarded adrenal development and delayed parturition. The precise mechanism whereby parturition is stimulated and controlled, however, remains something of a mystery in this polytocous species (Macdonald, 1979; Silver et al., 1979).

\section{The body frame}

A general impression of the growth in bone and skeletal muscle may be gained from the changes seen in the shape of the foetal body as gestation progresses. The limbs grow larger, the body's length to girth ratio increases and the head becomes less rounded and takes on a more blunted conical shape (Patten, 1931). 


\section{THE SKELETON}

Growth of the limb bones, seen radiographically as changes in the length of calcified diaphyses, occurs at rates which are constant for individual bones but which differ between bones (Hodges, 1953; Wenham, McDonald and Elsley, 1969; Gjesdal, 1972; Wrathall, Bailey and Hebert, 1974). However, these simple linear relationships of bone growth to age belie the complex three-dimensional processes of anabolism and catabolism occurring within the tissue itself (Patten, 1931; Vaughan, 1980). The growth observed radiographically is ossification of the bone. This is a process which involves, firstly, the degeneration of collagen cells in the diaphysis; an initial tissue calcification then follows which is in turn followed by extensive remodelling of the bone's internal structure. This latter process involves both deposition and excavation of calcified tissue (Vaughan, 1980). The actual increase in length of limb bones is produced by growth of cartilage cells which constitute the epiphyseal plates and which precede the region of ossification.

Radiography has also demonstrated that ossification centres other than those in the diaphyses appear and develop in the epiphyses during gestation. The appearance of the majority of these secondary ossification centres within the last three weeks of gestation (Wrathall, Bailey and Hebert, 1974) may be indicative of changes in the factors controlling bone growth. As mentioned earlier (p.382), cortisol, thyroxine and insulin are present in the foetal circulation during this period, as are somatomedin, calcitonin and parathyroid hormone (Phillippo, Care and Hinde, 1969; Littledike, Arnaud and Whipp, 1972; Care et al., 1978; Ross et al.,1980; Charrier, 1980). Moreoever the latter two hormones, together with 1,25-dihydroxycholecalciferol have been shown to influence, or be influenced by, circulating concentrations of calcium in the foetus. However, the nature of the interactions between these hormones and their role in foetal bone growth remains a subject for future study.

The skeleton is the basic frame to which the skeletal muscles attach and it would seem relevant to ask whether the growth in muscle influences bone growth, and if so to what extent. Just such an approach was earlier taken by Carey (1922-23) in his analysis of the early morphogenesis of the hind limb. As indicated above, there are changes taking place in bone shape and he interpreted these to be the result, in part, of associated skeletal muscle development.

\section{THE SKELETAL MUSCULATURE}

Currently the development of foetal muscle is being studied with a view to understanding its basic biochemistry and microscopic anatomy (Swatland and Cassens, 1973; Ashmore, Addis and Doerr, 1973; Ward, 1978b). Although the presence of primary and secondary muscle fibre types has been known for some time (Schwann, 1839) it is as a consequence of recent work that we know that primary fibres form the structural framework upon which the formation and subsequent growth of secondary fibres takes place. The latter rapidly increase in number between 50 and 70 days of 
gestation and their histochemical differentiation into slow-contracting, fatigue-resistant Type I fibres or fast-contracting, fatigue-sensitive Type II fibres would seem to be neurally regulated (Beermann, Cassens and Hausman, 1978; Szentkuti and Cassens, 1979). After about 70 days of gestation muscle tissue grows by hypertrophy of the individual myofibrils and the primary muscle fibres assume a more developed morphology shortly before birth.

The competence of foetal limb and neck muscles to contract and relax may be seen early in the second month of gestation in response to electrical or touch stimulation (Carey, 1922-23; Macdonald, unpublished observations). Similarly, foetal breathing, gasping and sighing movements, the result of movement by the diaphragm and/or intercostal muscles are observed during gestation (Randall, 1978; 1979).

The way in which these movements develop, and the manner in which they become coordinated remains unclear. Very little appears to be known about the prenatal development of functional bone-skeletal muscle relationships (Ward, 1978a, b).

\section{The defence of the individual}

Many separate factors, acting individually or in concert, constitute the defence of the newborn piglet. It is necessary to present only one or two examples to give an impression of their range and variety.

\section{ENERGY RESERVES}

Energy reserves are required to give the piglet a measure of protection against hypoxia during the birth process and heat loss following birth; in addition, they cover the temporary break in nutrient uptake as a consequence of the move from a placental to an alimentary supply. However, the piglet is born with little or no reserves of fat (Widdowson, 1950). It relies on the glucose deposited as glycogen in the liver, heart and skeletal muscle during the last month of gestation (Padalikova, Holub and Jezkova, 1972; Randall and l'Ecuyer, 1976). Although the glycogen in the liver and heart may be mobilized by the foetus at any time during the last two or three weeks of gestation (Comline, Fowden and Silver, 1979; Randall, 1979), the largest proportion of the body's energy reserves, representing $90 \%$ of body glycogen content, is in the skeletal musculature (Macdonald, 1974; Okai et al., 1978). These reserves are mobilized after birth, partly for locomotion and partly for body temperature maintenance.

\section{AGGRESSIVENESS}

Newborn piglets spend time competing aggressively with one another to establish a 'teat order' (Hartsock, Graves and Baumgardt, 1977; Fraser et al., 1979), those heavier at birth tending to win more fights and successfully defend their teat. Teeth are used actively in these encounters and it is of 
interest to note that these weapons erupt as early as 90 days of gestation (Gjesdal, 1972) and increase in size up until birth.

\section{IMMUNITY}

Immunoresistance to infection is not transferred across the placenta during gestation in the pig (Brambell, 1970). Protection is afforded first by the non-selective absorption of colostral immunoglobulins during the 24 hours after birth, and thereafter partly by the wash of milk immunoglobulins over the piglet's gut lumen and partly as a result of the rapid activation of the piglet's own immune system (Porter, 1979).

The gastric mucosa of the stomach develops during the second half of gestation (Figure 18.12(a) and (b)) such that although the stomach contents have an acid $\mathrm{pH}$ (Macdonald, unpublished observations) and prochymosin may be detected about three weeks before birth, no pepsin is present until about five days after birth; this is consistent with the period of early absorption of antibodies from colostrum as pepsin has the ability to cleave immunoglobulins (Tudor, Schofield and Titchen, 1977; Foltmann et al., 1981). Although the development of the intestine begins earlier than that

(a)

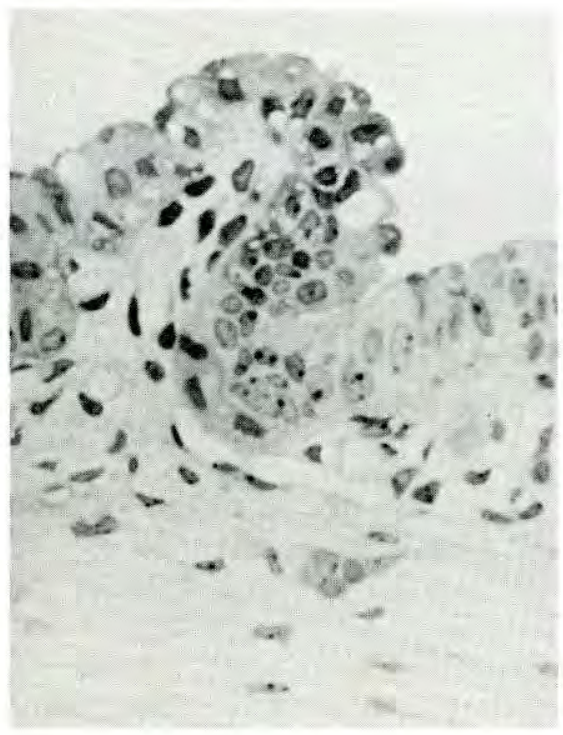

(b)

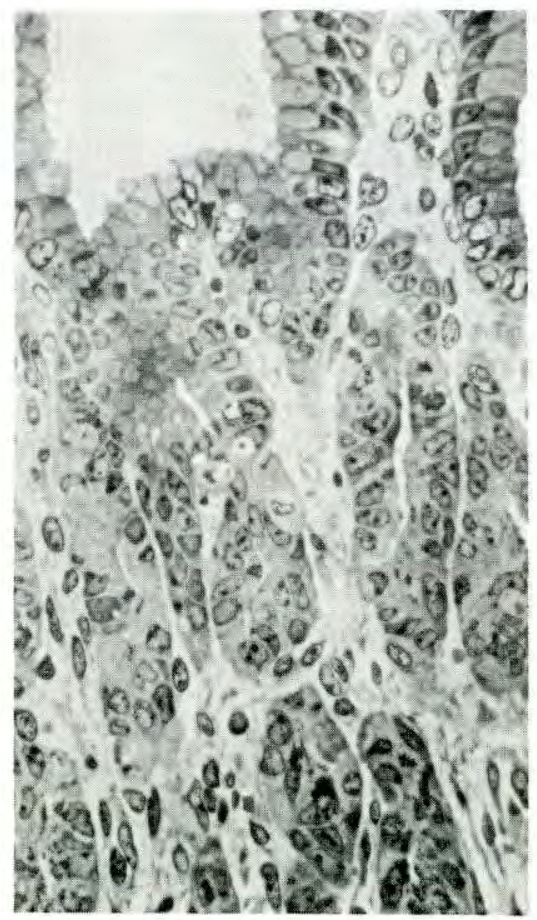

Figure 18.12 (a) Section of foetal pig stomach at 70 days of gestation illustrating only slight folding of the lining epithelium. (b) Section of foetal pig stomach at 112 days of gestation illustrating the deep invagination and glandular development of the stomach body. (Magn. $\times 350$ ) 
of the stomach (Lindberg and Karlsson, 1970; Hardy, Hockaday and Tapp, 1971; Karlsson, 1972) it only proceeds to a stage consistent with the passage and intact absorption of colostral gammaglobulins at birth (Lecce and Morgan, 1962; Burton and Smith, 1977).

Lymphoid differentiation occurs early in the second month of gestation (Chapman, Johnson and Cooper, 1974; Kovaru and Jaroskova, 1979) and piglets after about mid-gestation respond to injected antigens with endogenous antibody production (Binns, 1967; Bourne et al., 1974). Evidence to support the view that this early immunological development may in the past have had, and may still have, functional significance was provided by a recent survey of more than eleven hundred foetal piglets (Chaniago et al., 1978). Immunoglobulins representative of autologous foetal antibody production were found in five foetuses.

\section{Conclusions}

This chapter has discussed the foetal development of an assortment of those components, examples only of the many subsystems, whose competence to function at birth can drastically affect the ability of the piglet to survive. Much is known; however, there are also very large areas of ignorance. The practical relevance of such knowledge may be questioned as most piglets normally survive. The important question remains, however; why do the few fail?

A greater understanding of how and when the separate parts of the piglet's physiology and endocrinology normally achieve competence would enable us to assist and to exert control over this critical part of reproduction.

\section{Acknowledgements}

Sincere gratitude is expressed to the Meat and Livestock Commission, the Fulbright Foundation and the Deutsche Forschungsgemeinschaft for financially supporting A.A. Macdonald to carry out parts of this work.

\section{References}

ADRIAN, E.D. (1943a). Sensory areas of the brain. Lancet ii, 33-36

ADRIAN, E.D. (1943b). Afferent areas in the brain of ungulates. Brain 66, $89-103$

ALT, J.M., COLENBRANDER, B., MACDONALD, A.A., MAESS, B. and BIERMANN, U. (1981). Development of glomerular and tubular function in fetal and newborn pigs and their response to hypotonic saline load. In Advances in Physiological Sciences, Vol. 11, Kidney and Body Fluids, (L. Takács, Ed.), pp. 125-129. Oxford, Pergamon Press

ARON, M. (1922). L'evolution morphologique et fonctionelle des ilots endocrines du pancreas embryonnaire. Archs Anat. Histol. Embryol. 1, 69-112 
ASHMORE, C.R., ADDIS, P.B. and DOERR, L. (1973). Development of muscle fibers in the foetal pig. J. Anim. Sci. 36, 1088-1093

ATINMO, T., BALDISAO, C., POND, W.G. and BARNES, R.H. (1976). Maternal protein malnutrition during gestation alone and its effect on plasma insulin levels of the pregnant pig, its foetuses and the developing offspring. $J$. Nutr. 106, 1647-1653

BARNES, R.J., COMLINE, R.S., DOBSON, A. and SILVER, M. (1979). On the presence of a ductus venosus in the foetal pig in late gestation. J. Devel. Physiol. 1, 105-110

BASKERVILLE, A. (1976). Histological and ultrastructural observations on the development of the lung of the foetal pig. Acta Anat. 95, 218-233

BEERMANN, D.H., CASSENS, R.G. and HAUSMAN, G.J. (1978). A second look at fibre type differentiation in porcine skeletal muscle. J. Anim. Sci. 46, $125-132$

BERGELIN, I.S.S. and KARLSSON, B.W. (1975). Functional structure of the glomerular filtration barrier and the proximal tubuli in the developing foetal and neonatal pig kidney. Anat. Embryol. 148, 223-234

BERTON, J.P. (1970). Augmentation du volume pulmonaire et ascites après ligature intrauterine de la trachea chez le foetus de porc miniature. $C . r$. Ass. Anat. 147, 140-150

BIERMANN, U., FORSLING, M.L., ELLENDORFF, F. and MACDONALD, A.A. (1979). The cardiovascular responses of the chronically catheterised pig foetus to infused lysine vasopressin and to haemorrhage. J. Physiol. 296, 28-29P

BINNS, R.M. (1967). Bone marrow and lymphoid cell injection of the pig fetus resulting in transplantation tolerance or immunity, and immunoglobulin production. Nature, Lond. 214, 179-181

BLAND, R.D., McMILLAN, D.D. and BRESSACK, M.A. (1977). Movement of water and protein in the fetal and newborn lung. Annls Rech. vet. 8, 418-427

BOSC, M., DU MESNIL DU BUISSON, F. and LOCATELLI, A. (1974). Mise en evidence d'un contrôle foetal de la parturition chez la truie. Interactions avec la fonction luteale. C. $r$. hebd. Sèanc. Acad. Sci., Paris D 278, $1507-1510$

BOURNE, F.J., CURTIS, J., JOHNSON, R.H. and COLLINGS, D.F. (1974). Antibody formation in porcine fetuses. Res. vet. Sci. 16, 223-227

BRADLEY, O.C. (1903). On the development and homology of the mammalian cerebellar fissures. J. Anat. Physiol. 37, 211-240

BRADLEY, R.M. and MISTRETTA, C.M. (1975). Fetal sensory receptors. Physiol. Rev. 55, 352-382

BRAMBELL, F.W.R. (1970). The transmission of passive immunity from the mother to young. In Frontiers of Biology, Volume 18, (A. Neuberger and E.L. Tatum, Eds.). Amsterdam, North-Holland

BRENNER, K.V., GURTLER, H. and REINHARDT, P. (1978). Zum Gehalt an ACTH im Blutplasma bei Feten und neugeborenen Ferkeln. Endokrino. logie 71, 154-158

BROOKS, C.C. and DAVIS, J.W. (1969). Changes in the perinatal pig. J. Anim. Sci. 29, 325-329

BURTON, K.A. and SMITH, M.W. (1977). Endocytosis and immunoglobulin transport across the small intestine of the newborn pig. J. Physiol., Lond. 270, 473-488 
CARE, A.D., PICKARD, D.W., ROSS, R., GAREL, J.M., PAPAPOUlOS, S., O'RIORDAN, J.L.H. and ROBINSON, J.S. (1978). Calcium homoeostasis in the foetus and the placental calcium pump. In Endocrinology of Calcium Metabolism, (D.H. Copp and R.V. Talmage, Eds.), p.380. Amsterdam, Excerpta Medica

CAREY, E.J. (1922-23). Direct observations on the transformation of the mesenchyme in the thigh of the pig embryo (Sus scrofa) with especial reference to the genesis of the thigh muscles, of the knee and hip joints, and of the primary bone of the femur. J. Morphol. 37, 1-78

CHANIAGO, T.D., WATSON, D.L., OWEN, R.A. and JOHNSON, R.H. (1978). Immunoglobulins in blood serum of foetal pigs. Aust. vet. J. 54, 30-33

CHAPMAN, H.A., JOHNSON, J.S. and COOPER, M.D. (1974). Ontogeny of Peyer's patches and immunoglobulin-containing cells in the pigs. $J$. Immunol. 112, 555-563

CHARRIER, J. (1980). Somatomedin-A (Sm-A) bioactivity in serum and amniotic fluid as related to weight in the fetal pig. Reprod. Nutr. Dével. 20 (1B), 301-310

CLEMENTS, L.P. (1938). Embryonic development of the respiratory portion of the pig's lung. Anat. Rec. 70, 575-595

COLEN̦BRANDER, B., KRUIP, Th.A.M., DIELEMAN, S.J. and WENSING, C.J.G. (1977). Changes in serum LH concentrations during normal and abnormal sexual development in the pig. Biol. Reprod. 17, 506-513

COLENBRANDER, B., MACDONALD, A.A., WONG, C.C. and PARVIZI, N. (1980). Plasma TSH, $\mathrm{T}_{4}$ and $\mathrm{T}_{3}$ concentrations in the perinatal pig. $J$. Endocr. 85, 38P-39P

COLENBRANDER, B., ROSSUM-KOK, C.M.J.E. van, STRAATEN, H.W.M. van, and WENSING, C.J.G. (1979). The effect of fetal decapitation on the testis and other endocrine organs in the pig. Biol. Reprod. 20, 198-204

COLENBRANDER, B., MACDONALD, A.A., MEIJER, J.D., ElLENDORFF, F., VAN DE WIEL, D.F.M. and BEVERS, M.M. (1982). Prolactin in the pig fetus. Eur. J. Obstet. Gynec. reprod. Biol. (in press)

COMLINE, R.S., FOWDEN, A.L. and SILVER, M. (1979). Carbohydrate metabolism in the fetal pig during late gestation. Quart. J. exp. Physiol. 64, 277-289

COMLINE, R.S., FOWDEN, A.L., ROBINSON, P.M. and SILVER, M. (1981). Morphological development of the endocrine tissue in the foetal pig pancreas. J. Physiol. 307, 11-12P

DICKERSON, J.W.T. and DOBBING, J. (1966). Prenatal and postnatal growth and development of the central nervous system of the pig. Proc. Roy. Soc. 166, 384-395

DICKERSON, J.W.T., MERAT, A. and WIDDOWSON, E.M. (1971). The effect of development on the gangliosides of pig brain. Biochem. J. 125, 40-41P

DONE, J.T. and HERBERT, C.N. (1968). The growth of the cerebellum in the foetal pig. Res. vet. Sci. 9, 143-148

DVORAK, M. (1972). Adrenocortical function in foetal, neonatal and young pigs. J. Endocr. 54, 473-481

ELLIS, H.K. and WATKINS, W.B. (1975). Ontogeny of the pig hypothalamic neurosecretory system with particular reference to the distribution of neurophysin. Cell Tiss. Res. 164, 543-557

ELSAESSER, F., ELLENDORFF, F., POMERANTZ, D.K., PARVIZI, N. and SMIDT, 
D. (1976). Plasma levels of luteinizing hormone, progesterone, testosterone and Salpha-dehydrotestosterone in male and female pigs during sexual maturation. J. Endocr. 68, 347-348

EVANS, J.R., ROWE, R.D., DOWNIE, H.G. and ROWSELL, H.C. (1963). Murmurs arising from ductus arteriosus in normal newborn swine. Circ. Res. 12, 85-93

FENGER, F. (1912). On the presence of active principles in the thyroid and suprarenal glands before and after birth. J. biol. Chem. 11, 489-492

FEVRE, J. (1975). Corticosteroides maternels et foetaux chez la truie en fin de gestation. C. r. hebd. Seanc. Acad. Sci., Paris Series D 281, 2009-2012

FLINT, J.M. (1900). The blood vessels, angiogenesis, organogenesis, reticulum, and histology, of the adrenal. Johns Hopkins Hosp. Rep. 9, 152-231

FLINT, J.M. (1906-07). The development of the lungs. Am. J. Anat. 6, 1-138 FOLTMANN, B., JENSEN, A.L., LONBLAD, P., SMIDT, E. and AXELSEN, N.H. (1981). A developmental analysis of the production of chymosin and pepsin in pigs. Comp. Biochem. Physiol. 68B, 9-13

FORSLING, M.L., MACDONALD, A.A. and ELLENDORFF, F. (1979). The neurohypophysial hormones. Anim. Reprod. Sci. 2, 43-56

FOWDEN, A.L., COMLINE, R.S. and SILVER, M. (1981). Insulin release in the chronically catheterised sow and fetus. In Advances in Physiological Sciences, Vol. 20: Advances in Animal and Comparative Physiology, (G. Pethes and V.L. Frenyo, Eds.), Oxford, Pergamon Press

FRANCE, V.M. (1976). Active sodium uptake by the skin of foetal sheep and pigs. J. Physiol. 258, 377-392

FRASER, A.F., NAGARATNAM, V. and CALLICOTT, R.M. (1971). The comprehensive use of Doppler ultrasound in farm animal reproduction. Vet. Rec. 88, 202-205

FRASER, D., THOMPSON, B.K., FERGUSON, D.K. and DARROCH, R.L. (1979). The "teat order" of suckling pigs. 3. Relation to competition within litters. J. agric. Sci., Camb. 92, 257-261

GJESDAL, F. (1972). Age determination of swine foetuses. Acta vet. scand., Suppl. 40, 1-29

GOOTMAN, P.M., BUCKLEY, N.M. and GOOTMAN, N. (1978). Postnatal maturation of the central neural cardiovascular regulatory system. In Fetal and Newborn Cardiovascular Physiology, Vol. 1: Developmental Aspects, (L.D. Longo and D.D. Reneau, Eds.), pp. 93-152. London, Garland Stpm.

GOOTMAN, P.M. BUCKLEY, N.M. and GOOTMAN, N. (1979). Postnatal maturation of neural control of the circulation. Rev. Perinatal Med. 3, 1-72

GOOTMAN, N., GOOTMAN, P.M., BUCKLEY, N.M., COHEN, M.I., LEVINE, M. and SPIELBERG, R. (1972). Central vasomotor regulation in the newborn piglet Sus scrofa. Am. J. Physiol. 222, 994-999

GOTTLIEB, G. (1971). Ontogenesis of sensory function in birds and mammals. In The Biopsychology of Development, (E. Tobach, L.R. Aronson and E. Shaw, Eds.), pp. 67-128. New York, Academic Press

GUYTON, A.C., COLEMAN, T.G. and GRANGER, H.J. (1972). Circulation: overall regulation. Ann. Rev. Physiol. 34, 13-46

HAM, A.W. and BALDWIN, K.W. (1941). A histological study of the develop- 
ment of the lung with particular reference to the nature of alveoli. Anat. Rec. 81, 363-379

HARDESTY, I. (1915). On the proportions, development and attachment of the tectorial membrane. Am. J. Anat. 18, 1-73

HARDY, R.N., HOCKADAY, A.R. and TAPP, R.L. (1971). Observations on the structure of the small intestine in foetal, neonatal and suckling pigs. Phil. Trans. Roy. Soc., Lond. 259B, 517-531

HARRIS, W.H. and CUMMINGS, J.N. (1973). Maternal and fetal responses to varying levels of oxygen intake in swine. J. appl. Physiol. 34, 584-589

HARTSOCK, T.G., GRAVES, H.B. and BAUMGARDT, B.R. (1977). Agonistic behaviour and the nursing order in suckling piglets: relationships with survival growth and body composition. J. Anim. Sci. 44, 320-330

HILL, E.C. (1905). On the first appearance of the renal artery, and the relative development of the kidneys and Wolffian bodies in pig embryos. Johns Hopkins Hosp. Bull. 16, 60-64

HODGES, P.C. (1953). Ossification in the fetal pig. Anat. Rec. 116, 315-325

JOPPICH, R., KIEMANN, U., MAYER, G. and HABERLE, D. (1979). Effect of antidiuretic hormone upon urinary concentrating ability and medullary c-AMP formation in neonatal piglets. Pediat. Res. 13, 884-888

KAMAN, J. (1968a). Der Umbau des Ductus Venosus des Schweines. 1. Pränatales Stadium. Anat. Anz. 122, 252-266

KAMAN, J. (1968b). Der Umbau des Ductus Venosus beim Schwein. II. Postnatales Stadium. Anat. Anz. 122, 476-486

KAPLAN, A. and FRIEDMAN, M. (1943). Studies concerning the site of renin formation in the kidney. III. The apparent site of renin formation in the tubules of the mesonephros and metanephros of the hog fetus. J. exp. Med. 76, 307-316

KARLSSON, B.W. (1972). Ultrastructure of the small intestine epithelium of the developing pig foetus. Z. Anat. EntwGesch. 135, 253-264

KATZNELSON, Z.S. (1965). Zur Fruhentwicklung der Nebenniere des Schweines. Z. mikrosk.-anat. Forsch. 73, 187-199

KATZNELSON, Z.S. (1966). Späthistogenese der Nebenniere des Schweines. Z. mikrosk.-anat. Forsch. 74, 193-208

KAZIMIERCZAK, J. (1970). Histochemical observations of the developing glomerulus and juxtaglomerular apparatus. Acta path. microbiol. scand. 78A, 401-413

KELLOGG, H.B. (1928). The course of the blood flow through the fetal mammalian heart. Am. J. Anat. 42, 443-465

KÖLLIKER, A. (1904). Die Entwicklung und Bedeutung des Glaskörpers. Z. wiss. Zool. 76, 1-25

KONDA, N., DYER, R.G., BRUHN, T., MACDONALD, A.A. and ELLENDORFF, F. (1979). A method for recording single unit activity from the brains of foetal pigs in utero. $J$. Neurosci. Meth. 1, 289-300

KORNGUTH, S.E., FLANGAS, A.L., GEISON, R.L. and SCOTT, G. (1972). Morphology, isopycnic density and lipid content of synaptic complexes isolated from developing cerebellums and different brain regions. Brain Res. 37, 53-68

KOVARU, F. and JAROSKOVA, L. (1979). Development of Erosette formation in ontogeny of pigs. Folia biol., Praha 25, 399-400

KRAELING, R.R., RAMPACEK, G.B., CAMPION, D.R. and RICHARDSON, R.L. 
(1978). Longissimus muscle and plasma enzymes and metabolites in fetally decapitated pigs. Growth 42, 457-468

KUNSKA, A. (1971a). Histological studies on the development of the kidney (metanephros) in embryos of the domestic pig. I. Folia morph. 30. 1-20 KUNSKA, A. (1971b). Histochemical study on the development of the kidney (metanephros) in embryos of the domestic pig. II. Folia morph. 30, 259-270

LARSELL, O. (1954). The development of the cerebellum of the pig. Anat. ReC. 118, 73-107

LECCE, J.G. and MORGAN, D.O. (1962). Effect of dietary regimen on cessation of intestical absorption of large molecules (closure) in the neonatal pig and lamb. J. Nutr. 78, 263-268

LINDBERG, T. and KARLSOON, B.W. (1970). Changes in intestinal dipeptidase activities during fetal and neonatal development of the pig as related to the ultrastructure of mucosal cells. Gastroenterology 59, 247-256

LITTLEDIKE, E.T., ARNAUD, C.D. and WHIPP, S.C. (1972). Calcitonin secretion in ovine, porcine and bovine fetuses. Proc. Soc. exp. Biol. Med. 139, 428-433

LIVETT, B.G., UTTENTHAL, L.O. and HOPE, D.B. (1971). Localisation of neurophysin-II in the hypothalamo-neurohypophysial system of the pig by immunofluorescence histochemistry. Phil. Trans. Roy. Soc. Lond. 261B, 371-378

LIWSKA, J. (1975). Development of the adenohypophysis in the embryo of the domestic pig. Folia morph. 34, 211-217

LIWSKA, J. (1978). Ultrastructure of the adenohypophysis in the domestic pig (Sus scrofa domestica). Part 1: Cells of the pars anterior. Folia histochem. cytochem. 16, 307-314

LOHSE, J.K. and FIRST, N.L. (1979). Development of the porcine fetal adrenal in late gestation: steroidogenesis and histology. Biol. Reprod. 20, Suppl. $1,126 \mathrm{~A}$

MACDONALD, A.A. (1971). The foetal and postnatal growth of Sus domesticus $\mathrm{L}$. with a study of the foetal-maternal placental vascularisation. Thesis. Glasgow University

MACDONALD, A.A. (1974). Studies into foetal and neonatal development of the pig (Sus scrofa L.). Thesis. Edinburgh University

MACDONALD, A.A. (1979). Patterns of endocrine change in the pig foetus. Anim. Reprod. Sci. 2, 289-304

MACDONALD, A.A. (1981). Studies on the anatomy and physiology of the pig fetus and placenta: an historical review. In Advances in Physiological Sciences, Vol. 21: History of Physiology, (E. Schultheisz, Ed.), pp. 53-60. Oxford, Pergamon Press

MACDONALD, A.A. and COLENBRANDER, B. (1981). Cardiovascular responses of the fetal pig to autonomic stimulation. In Advances in Physiological Sciences, Vol. 8: Cardiovascular physiology: Heart, Peripheral circulation and Methodology, (A.G.B. Kovach, E. Monos and G. Rubany, Eds.), pp. 319-325. Oxford, Pergamon Press

MACDONALD, A.A., RUDOLPH, A.M. and HEYMANN, M.A. (1980). The pig placenta: vascular anatomy and blood flow. Proc. Int. Symp. Primate Non-Primate Placental Transfer, Rotterdam (Abstract)

MACDONALD, A.A., COLENBRANDER, B., MEIJER, J.C., POOT, P. and WENSING, C.J.G. (1981a). Development of innervation to the heart of the pig fetus. Acta morph. neerl. scand. 19, 257-258 
MACDONALD, A.A., FORLING, M:L., WILLIAMS, H. and ELLENDORFF, F. (1979). Plasma vasopressin and oxytocin concentrations in the conscious pig foetus: response to haemorrhage. $J$. Endocr. 81, 124P-125P

MACDONALD, A.A., LLANOS, A.J., HEYMANN, M.A. and RUDOLPH, A.M. (1981b). Cardiovascular responsiveness of the pig fetus to autonomic blockade. Pfluger's Arch. ges. Physiol. 390, 262-264

McCANCE, R.A. and STANIER, M.W. (1960). The function of the metanephros of foetal rabbits and pigs. $J$. Physiol. 151, 479-483

MAJSTRUK-MAJEWSKA, T. (1966). Histochemistry of some lipids in the course of myelinisation of the spinal cord in domestic pig. Annls Univ. Marie Curie-Sklodowska 21 DD, 1-18

MARSHALL, A.E. and BREAZILE, J.E. (1974a). Localization of cardiovascular centers in myelencephalon of newborn and older pigs. Am. J. vet. Res. 35, 223-229

MARSHALL, A.E. and BREAZILE, J.E. (1974b). Evidence for maturation of myelencephalic cardiovascular control in the postnatal pig. Am. J. vet. Res. 35, 231-236

MATTSSON, J.L., FRY, W.N., BOWARD, C.A. and MILLER, E. (1978). Maturation of the visual evoked response in newborn miniature pigs. Am. J. vet. Res. 39, 1279-1281

MEBAN, C. (1980). Surface elastic properties of surfactant from the lungs of neonatal pigs. Biol. Neonate 37, 308-312

MELAMPY, R.M. HENRICKS, D.M., ANDERSON, L.L., CHEN, C.L. and SCHULTE, J.R. (1966). Pituitary follicle-stimulating hormone and luteinizing hormone concentrations in pregnant and lactating pigs. Endocrinology 78, 801-804

MILLER, J.A. and MILLER, F.S. (1965). Studies on prevention of brain damage in asphyxia. Dev. Med. Child Neurol. 7, 607-619

MOODY, R.O. (1906). Some features of the histogenesis of the thyroid gland in the pig. Anat. Rec. 4, 429-452

NELSON, W.O. (1933). Studies on the anterior hypophysis. I. The development of the hypophysis in the pig (Sus scrofa). II. The cytological differentiation in the anterior hypophysis of the foetal pig. Am. J. Anat. 52, 307-332

NICHOLAS, T.E., JOHNSON, R.G., LUGG, M.A. and KIM, P.A. (1978). Pulmonary phospholipid biosynthesis and the ability of the fetal rabbit lung to reduce cortisone to cortisol during the final ten days of gestation. Life Sci. 22, 1517-1524

OKAI, D.B., WYLLIE, D., AHERNE, F.X. and EWAN, R.C. (1978). Glycogen reserves in the fetal and newborn pig. J. Anim. Sci. 46, 391-401

OLSON, E.B. (1979). Role of glucocorticoids in lung maturation. J. Anim. Sci. $49,225-238$

OSBORN, J.L. (1979). Immaturity of renal function in newborn pigs: factors affecting renal hemodynamics, sodium excretion and plasma renin activity. PhD Thesis. Michigan State University

PADAlikovA, D., HOLUB, A. and JEZKOVA, D. (1972). Glycogen in the placenta and pig foetus tissues in the last third of intra-uterine life. Vet. Med., Praha 17, 649-656

PATTEN, B.M. (1931). The Embryology of the Pig. Philadelphia, Blakiston

PATTERSON, D.S.P., DONE, J.T., FOULKES, J.A. and SWEASY, D. (1976). Neurochemistry of the spinal cord in congenital tremor of piglets (type 
A11) a spinal dysmyelinogenesis of infectious origin. J. Neurochem. 26, 481-485

PERKS, A.M. and VIZSOLYI (1973). Studies of the neurohypophysis in foetal mammals. In Foetal and Neonatal Physiology, (R.S. Comline, K.W. Cross, G.S. Dawes and P.W. Nathanielsz, Eds.), pp. 430-438. Cambridge, University Press

PERRY, J.S. and STANIER, M.W. (1962). The rate of flow of urine of foetal pigs. J. Physiol. 161, 344-350

PHILLIPPO, M., CARE, A.D. and HINDE, F.R. (1969). The effect of thyrocalcitonin in neonatal animals. $J$. Endocr. $43, \mathrm{XV}-\mathrm{XVI}$

POHLMAN, A.G. (1909). The course of the blood through the heart of the fetal mammal, with a note on the reptilian and amphibian circulations. Anat. Rec. 3, 75-109

POMEROY, R.W. (1960). Infertility and neonatal mortality in the sow. III. Neonatal mortality and foetal development. J. agric. Sci., Camb. 54, $31-56$

PORTER, P. (1979). Structural and functional characteristics of immunoglobulins of the common domestic species. Adv. vet. Sci. comp. Med. 23, $1-21$

PRENTISS, C.W. (1913). On the development of the mebrana tectoria with reference to its structure and attachments. Am. J. Anat. 14, 425-459

RABL, C. (1900). Uber den Bau und die Entwicklung der Linse. III. Die Linse der Säugetiere. Ruckblick und Schluss. Z. wiss. Zool. 67, 1-138

RANDALL, G.C.B. (1978). Perinatal mortality: some problems of adaptation at birth. Adv. vet. Sci. comp. Med. 22, 53-81

RANDALL, G.C.B. (1979). Studies on the effect of acute asphyxia on the fetal pig in utero. Biol. Neonate 36, 63-69

RANDALL, G.C.B. and I'ECUYER, C. (1976). Tissue glycogen and blood glucose and fructose level in the pig fetus during the second half of gestation. Biol. Neonate 28, 74-82

ROSS, R., CARE, A.D., PICKARD, D.W., GAREL. J.M. and WEATHERLEY (1980). Placental transfer of calcium in the pig. $J$. Endocr. 85, 53P-54P

ROWE, R.D., SINCLAIR, J.D., KERR, A.R. and GAGE, P.W. (1964). Duct flow and mitral regurgitation during changes of oxygenation in newborn swine. J. appl. Physiol. 29, 1157-1163

RUFER, R. and SPITZER, H.L. (1974). Liquid ventilation in the respiratory distress syndrome. Chest 66, Suppl. 29S-30S

SCHWANN, T. (1839). Mikroskopische Untersuchungen über die Ubereinstimmung in der Struktur und dem Wachstume der Tiere und Pflanzen.

SEDOVA, E.V. (1974). The fetal cortex and X-zone in the adrenal gland of some mammals. Archs Anat. Histol. Embryol. 66, 77-82

SILVER, M., FOWDEN, A.L., COMLINE, R.S., CLOVER, L. and MITCHELL, M.D. (1979). Prostaglandins in the foetal pig and prepartum endocrine changes in mother and foetus. Anim. Reprod. Sci. 2, 305-322

STANTON, H.C. and WOO, S.K. (1978). Development of adrenal medullary function in swine. Am. J. Physiol. 234, E137-E145

STANTON, H.C., CORNEJO, R.A., MERSMANN, H.J., BROWN, L.J. AND MUELLER, R.L. (1975). Ontogenesis of monoamine oxidase and catechol-Omethyl transferase in various tissues of domestic swine. Archs int. Pharmacodyn. Ther. 213, 128-144 
STARLING, M.B., NEUTZE, J.M., ELLIOTT, R.L. and ELLIOT, R.B. (1976). Studies on the effects of prostaglandins $E_{1}, E_{2}, A_{1}$ and $A_{2}$ on the ductus arteriosus of swine in vitro using cineangiography. Prostaglandins 12, 335

STARLING, M.B., NEUTZE, J.M., ELLIOTT, R.L., TAYLOR, I.M.M. and ELLIOTT, R.B. (1978). The effects of some methyl prostaglandin derivatives on the ductus arteriosus of swine in vivo. Prostaglandins Med. 1, 267-281

STRYKER, J.L. AND DZIUK, P.J. (1975). Effects of fetal decapitation on fetal development parturition and lactation in pigs. J. Anim. Sci. 40, 282-287

STUDZINSKI, T., BOBOWIEC, R. and RYBKA, A. (1976). Histomorphological and functional development of thyroid gland in the pig during embryonic and postnatal state. Annls Univ. Marie Curie-Sklodowska 31 DD, 119-128

SWATLAND, H.J. and CASSENS, R.G. (1973). Prenatal development histochemistry and innervation of porcine muscle. J. Anim. Sci. 36, 343-354

SZALAY, K.S. and GYEVAI, A. (1967). Renin production by tissue cultures of renal cortex. Life Sci. 6, 925-928

SZENTKUTI, L. and CASSENS, R.G. (1979). Motor innervation of myofiber types in porcine skeletal muscle.J. Anim. Sci. 49, 693-700

TOO, K., KAWATA, K., FUKUI, Y., SATO, K., KAGOTA, K. and KAWABE, K. (1974). Studies on pregnancy diagnosis in domestic animals by an ultrasonic Doppler method. 1. Jap. J. vet. Res. 22, 61-71

TUDOR, E.M., SCHOFIELD, G.C. and TITCHEN, D.A. (1977). Structural and functional development of the gastric parietal cell population in the newborn pig. Annls Recherch. Vet. 8, 450-459

VAN NIE, C.J., VERSPRILLE, A., GIESBERTS, M.A.H., RIEDSTRA, J.W., BENEKEN, J.E.W. and ROHMER, J. (1970). Functional behaviour of the Foramen ovale in the newborn piglet. Pfluger's Arch. ges. Physiol. 314, 154

VAUGHAN, J. (1980). Bone growth and modelling. In Growth in Animals. (T.L.J. Lawrence, Ed.), pp. 83-99. London, Butterworths

VERHOFSTAD, A.A.J., STEINBUSCH, H.W.M., JOOSTEN, H.W.J., COLENBRANDER, B. and MACDONALD, A.A. (1981). Development of the noradrenaline and adrenaline-storing cells in the adrenal medulla and its control by the adrenal cortex. Acta morph. neerl-scand. 19, 330

VERSPRILLE, A., SOETEMAN, D.W., STULE, J. and VAN NIE, C.J. (1970). Flow resistance of the foramen ovale in newborn pigs. Pfluger's Arch. ges Physiol. 318, 269

VESALIUS, A. (1543). De humani corporis fabrica. Oporinus, Baseleae

WARD, P.S. (1978a). The splayleg syndrome in newborn pigs. A review. Part 1. Vet. Bull. 48, 279-295

WARD, P.S. (1978b). The splayleg syndrome in newborn pigs. A review. Part 2. Vet. Bull. 48, 381-399

WELENTO, J. (1960). Statistical investigations on the correlation between the weight of the brain and the weight and length of the foetuses of the Pulawska pig. Annls Univ. Marie Curie-Sklodowska 15, 81-84

WELENTO, J. (1961). The development of the cerebrum trunk in the pig. Annls Univ. Marie Curie-Sklodowska 16 DD, 87-101

WENHAM, G., MCDONALD, I. and ELSLEY, F.W.H. (1969). A radio-graphic study of the development of the skeleton of the foetal pig. J. agric. Sci., Camb. 72, 123-130 
404 Physiology and endocrinology of the foetus in late gestation

WENSING, C.J.G. (1964). The conductive system and its nervous component in the pig's heart. PhD Thesis. Utrecht

WEYMANN, M.F. (1922-23). The beginning and development of function in the suprarenal medulla of pig embryos. Anat. Rec. 24, 299-313

WHITEHEAD, R.H. (1903). The histogenesis of the adrenal in the pig. Am.J. Anat. 2, 349-360

WIDDOWSON, E.M. (1950). Chemical composition of newly born mammals. Nature, Lond. 166, 626-628

WIESEL, J. (1901). Uber die Entwicklung der Nebenniere des Schweines besonders der Markșubstanz. Anat. Hefte 16 S, 117-148

WOOLSEY, C.N. and FAIRMAN, D. (1946). Contralateral, ipsilateral, and bilateral representation of cutaneous receptors in somatic areas I and II of the cerebral cortex of pig, sheep and other mammals. Surgery 19, 684-702

WRATHALL, A.E., BAILEY, J. and HEBERT, C.N. (1974). A radiographic study of development of the appendicular skeleton in the fetal pig. Res. vet. Sci. 17, 154-168

ZIOLO, I. (1965). Myelinization of nerve fibres of pig spinal cord. Acta Anat. 61, 297-320 